\title{
Y KUŞAĞI VE FACEBOOK: Y KUŞAĞININ FACEBOOK KULLANIM ALIŞKANLIKLARI ÜZERINE BİR İNCELEME
}

\author{
Y GENERATION AND FACEBOOK: A RESEARCH ON THE USE HABITS OF \\ FACEBOOK OF Y GENERATION
}

Mihalis KUYUCU *

\begin{abstract}
Öz
Bu çalışmada 1979 ile 1999 yılları arasında doğan ve Y kuşağı olarak adlandırılan yeni nesil gençlerin sosyal medya ağı Facebook'u kullanma alışkanlıkları üzerine bir araştırma yapılmıştır. Çalışmanın birinci bölümünde kuşaklar ile ilgili kavramsal tarama yapılmış ve Y kuşağının özellikleri yapılan güncel saha araştırmalarına paralel olarak tanımlanmıştır. İkinci bölümde gelecekte dünyaya yön veren nesil olarak adlandırılan Y kuşağının Facebook'u kullanım biçimleri üzerine araştırma yapılmıştır. Güvenilir sonuçlar veren araştırmada Y kuşağının Facebook kullanma nedenleri araştırılmıştır. Araştırmada ayrıca Y kuşağının Facebook için iddia konusu olan 'bağımlılık yaratıyor' yargısına yönelik görüşleri değerlendirilmiş ve Y kuşağının bu yargıya cinsiyet ve yaşa göre yüzde yüz bir katılım sağlamadıkları tespit edilmiştir. Araştırmanın son bölümüne Y kuşağının Facebook adlı sosyal ağı kullanım biçimlerinin yaşa ve cinsiyete göre farklılıkları tespit edilmiş ve kuşak üyelerinin ait oldukları dönemde yaşanan teknolojik ve internet mecrasında yaşanan gelişmelere paralel olarak iki alt gruba ayrılması gerektiği vurgulanmıştır.
\end{abstract}

Anahtar Kelimeler: Y Kuşağı, Facebook, Sosyal Medya, Yeni medya

\begin{abstract}
In this study there has been a research on the usage of Facebook for the generation that was born between 1979 and 1989 which is called as Y Generation. In the first part of the study a conceptual research for the concept of Y generation was done and it the specifications of this generation through the light of the current researches done until now were shown. In the second part of the study there has been a research which gave reliable results on how the Y generation uses Facebook. On the research there has been also an evaluation on the idea of 'Facebook makes dependence' by the side of the Y generation and there has been found a result that Y generation doesn't full accept that Facebook makes dependence. In the final stage of the research there has been an evaluation for $Y$ generation's use of Facebook according to age and sex and there has been a determination that this generation should be divided in to two subparts according to the technological and internet developments during their period.
\end{abstract}

Key Words: Y Generation, Facebook, Social Media, New Media

\footnotetext{
* Yrd.Doç.Dr.Mihalis Kuyucu, İstanbul Aydın Üniversitesi Öğretim Üyesi, Radyo \& TV Program Yapımcısı, michael@michaelshow.net
} 


\section{GİRIŞ}

Dört buçuk milyar yaşında olan dünyada insanlığın oluşması yaklaşık yüz yıl öncesine dayanan memelilerin evrimleşmesi ile başlamıştır. Memeli hayvanların evrimleşmesi ile başlayan ve günümüze kadar gelişen insanlık tarihi önce fiziki evrimini tamamlamış daha sonra da tarihsel süreçler içinde sosyolojik ve kültürel bir evrim geçirmiştir. İnsanların fiziki evrimlerini tamamlaması sonucunda ortaya çıkan uygarlıklar temel ihtiyaçlarının temininin yanı sıra dünya üzerinde yaşadıkları coğrafyalara hâkim olmak için savaşmışlardır. İnsanlık tarihi ikinci dünya savaşına kadarki süreçte bu mücadeleye şahit olmuş ve gelişimini tarihsel dönemler içinde yaşananlarla sağlamışlardır. Bu dönemlerde uygarlıkların yaşam mücadelesi sonucunda oluşan olaylar onları farklı çağlar altında kategorize edilmesine neden olmuştur.1453 yılında İstanbul'un Fethi ile yeniçağ başlarken, 1789 yılında yapılan Fransız İhtilali yakın çağın başlamasına neden olmuştur. Bu benzeri tarihsel döngüler toplumların sadece coğrafi değil aynı zamanda kültürel gelişimini de etkilemiştir. Her yeni dönem aynı zamanda toplumsal ve kültürel anlamda bir değişimin de habercisi olmuş ve insanlık yaşam kalitesini bu dönemlerde ki edinimleri ile değiştirmiştir.

$\mathrm{Bu}$ tarihsel dönüşüm sıcak çatışmaların en büyüğünün bittiği ikinci dünya savaşı ile soğuk çatışmaların bittiği soğuk savaş dönemi sonuna kadar devam etmiştir. Soğuk savaş yıllarının bitmesi insanlık tarihi açısından ayrı bir kırılma noktası olmuştur. Soğuk savaşın olası bir sıcak savaşa dönüşmesi ihtimali üzerine askeri amaçlarla icat edilen internet teknolojisinin yarattığı dönüşüm dünyayı özellikle son yirmi yılda farklı bir noktaya getirmiştir. Soğuk savaş sona ermiş yerine serbest piyasa ekonomisinin yarattığı liberal düzen gelmiş ve tüketim toplumu ile teknoloji dönemi başlamıştır. Teknoloji dünyasında yaşanan gelişmeler insanlık için farklı bir dönemin başlamasına neden olmuştur. İkinci dünya savaşına kadar tarihsel dönemler ışığında tanımlanan kuşaklar bu dönemden sonra teknolojinin 1şı ğında tanımlanmaya başlamıştır. Bu nedenledir ki kuşaklar 1965 yılından sonra tarihsel olaylar 1şığında değil sosyolojik gelişmelere paralel olarak tanımlanmıştır. Önce X kuşağı daha sonra teknoloji ile gelişen Y kuşağı tanımı yapılmış en son da hayatını teknoloji ile iç içe yaşayan Z kuşağı tanımlanmıştır.

$\mathrm{Bu}$ üç kuşağın öncekilerden en büyük farkı sıcak veya soğuk savaşların yarattığı dönemler ile değil teknolojik gelişmelerle tanımlanabilmesidir. Teknolojinin dünyaya hâkim olduğu bir yüzyılda gelişen insanlığın ortalama yirmişer yıllık aralıklarla farklı özellikle taşıyan gruplara bölünmesi ise teknolojinin insanlık üstündeki hızlı etkisini göstermiştir. $\mathrm{Bu}$ çalışmada teknoloji ile iç içe büyüyen bir kuşak olan Y kuşağının bir teknoloji ürünü olan 
sosyal medya ve onun platormu Facebook ile olan etkileşimi üzerinde bir araştırma yapılmıştır.

\section{KUŞAK KAVRAMI VE Y KUŞAĞI}

Türk Dil Kurumu sözlüğü kuşak kavramını aşağı yukarı aynı yıllarda doğmuş olup aynı çağın koşullarını, dolayısıyla birbirine benzer sıkıntıları, yazgıları yaşamış, benzer ödevlerle yükümlü olmuş kişiler topluluğu olarak tanımlamaktadır (http:www.tdkterim.gov.tr). Lower (2008:81 her kuşağın kendine özgü özellikleri, değer yargıları, tutumları, güçlü ve zayıf yönlerinin olduğunu belirtmiştir.

Araştırmacılar kuşakları belirli tarihsel dönemler içerisinde değerlendirmişler ve kuşaklar her dönem içinde farklı isimlerle kategorileştirilmiştir. Geçmişten bugüne kuşaklar beş farklı grup altında sınıflandırılmıştır. Bunlar (Williams ve Page,2011:2-8):

Tablo 1. Kuşaklar ve Dönemleri

\begin{tabular}{|l|}
\hline Gelenekselciler (1930-1945) \\
\hline Bebek Patlaması (1946-1964) \\
\hline X Kuşağı (1965-1976) \\
\hline Y Kuşağı (1977-1994) \\
\hline Z Kuşağı (1994 ve sonrası) \\
\hline
\end{tabular}

Kuşaklar ile ilgili farklı yılları kapsayan farklı gruplandırılmalar yapılmaktadır. Bu konuda yapılan ve literatürde en çok kullanılan gruplandırma ise şöyledir (Dijital Ajanslar,2013):

Tablo 2. Dünyada Yaygın Olarak Kullanılan Kuşak Tanımları ve Dönemleri

\begin{tabular}{|l|}
\hline Sessiz Kuşak ( Savaş Kuşağı - Silent Generation) (1927-1945) \\
\hline Büyük Bebek Patlaması ( The Baby Boomers Generation) (1946-1965) \\
\hline X Kuşağı (Gen X - Baby Busters) (1965-1979) \\
\hline Y Kuşağı ( Echo Boom - Millenials) (1979-1999) \\
\hline Z Kuşağı ( Gen Z) ( 2000 ve sonrası) \\
\hline
\end{tabular}

Yaşadıkları dönemlerde meydana gelen tarihsel olaylardan derin etkilenen kuşaklar ait oldukları dönemlerin izlerini de taşımaktadırlar. "Sandviç Kuşağı" olarak da adlandırılan Baby Boomer Kuşağı aynı evde önce çocuklarına daha sonra da yaşlanan anne ve babalarına bakmışlardır. Radyonun altın çağını yaşayan bu kuşak ikinci dünya savaşından hemen sonraki nüfus patlaması yıllarında doğan 1 milyar bebek içinde yer aldıkları için Baby Boomers adı verilmiştir (Kariyer Atölyesi,2003). X Kuşağı ise 1965 - 1979 yılları arasında 
doğan daha çalışkan, realist ve kanaatkâr kuşak olarak tanımlanmıştır. Bu kuşağın yetiştiği dönem petrol krizleri ve ekonomik krizlerle geçmiştir ( Dijital Ajanslar,2013).

Kuram Türkiye'deki kuşakları şöyle sınıflandırmıştır (Ergil,2013:13):

Tablo 3. Türkiye'de Kuşaklar ve Dönemleri

\begin{tabular}{|l|l|l|}
\hline Kuşak Adı & Dönem & Türkiye'deki Oranları \\
\hline Sessiz Kuşak & $1927-1945$ & Ülke nüfusunun \%7'si \\
\hline Kentlileşen Kuşak & $1946-1964$ & Ülke nüfusunun \% 19'u \\
\hline X Kuşağ1 & $1965-1979$ & Ülke nüfusunun \% 22'si \\
\hline Y Kuşağ1 & 1980-1999 & Ülke nüfusunun \% 35'i \\
\hline Z Kuşağ1 & $\begin{array}{l}\text { 2000 yılı ve sonrasında } \\
\text { doğanlar }\end{array}$ & Ülke nüfusunun \%17'si \\
\hline
\end{tabular}

Hay Group'un gerçekleştirdiği 'Gençler 'İŞ’e El Koydu' adlı araştırmasına göre kuşakların özellikleri ve güçlü oldukları noktalar arasında belirgin farklılıklar bulunmaktadır (Para, 2013:34):

Tablo 4. Kuşakların Karakteristik Özellikleri

\begin{tabular}{|l|l|l|}
\hline Kuşak & Genel Özellikleri & Güçlü Noktaları \\
\hline Sessiz Kuşak & Pratik, rasyonel & İstikrar, bağlılık \\
\hline Baby Boomers & İyimser, pozitif & Ekip çalışması, bağlılık \\
\hline X Kuşağı & Şüpheci, dikkatli & $\begin{array}{l}\text { Uyumluluk, uzlaşma, bilgi teknolojileri } \\
\text { bilgisi }\end{array}$ \\
\hline Y Kuşağı & Umutlu, güvenli & Aynı anda çok iş yapma, teknoloji becerisi \\
\hline
\end{tabular}

Y Kuşağının hangi tarihte doğanları kapsadığı konusunda literatürde görüş farklılıkları vardır. Bazı araştırmacılara göre Y Kuşağı 1980-2000 yılları arasında doğanları kapsarken (Miller ve Washington, 2011:174) bazılarına göre de 1977 - 2000 yılları arasında doğanlar Y Kuşağı kapsamına girmektedir (Kotler ve Armstrong , 2004:465). Y Kuşağı adını İngilizce 'deki “why” kelimesinden almıştır. İngilizce 'de "neden?” anlamına gelen “why” kelimesi Y harfi ile sesteş olduğundan bu kuşak adını bu kelimeden almıştır. Y Kuşağı hayatın her alanını sorgulayan irdeleyen ve yükümlülükleri eleştiren yapısı ile bu adı alırken "why” kelimesi ile özdeşleşmesine neden olmuştur (http:www.aksam.com.tr Erişim Tarihi: 08 Haziran 2013). Y Kuşağ1 aynı zamanda internet kuşağ1, echo-boomers, millenial ve nexters olarak da anılmaktadır. Bu tanımlar Y Kuşağının kendisinden önce gelen kuşaklardan farkını belirtmek için kullanılmaktadır (Broadbirdge, Maxwell vd,2007:135). Y Kuşağı terimi tarihte ilk kez 
1993 yılının Ağustos ayında o zaman ki gençlerin önceki X Kuşağı olarak adlandırılan kuşaktan farklarını ifade etmek amacıyla kullanılmıştır (Straus ve Howe, 1992:54).

Edelman 8095 Araştırma Grubu Direktörü Alex Abraham Y Kuşağının günümüzde çok önemli ve stratejik bir konumda bulunduğunu belirtmiştir. Abraham 2013 yılı itibariyle bu kuşağın en küçük üyelerinin 18, en büyük üyelerinin ise 33 yaşında olacağının altını çizmiş ve bu kuşağın hem bugünün dünyasına yön verdiğini hem de büyük bir harcama gücünü ellerinde bulundurduğunu belirtmiştir. Abraham “ 2025 yılı itibariyle dünyada çalışan nüfusun \% 70'ini Y Kuşağı oluşturacak” demiştir ( Marketing Türkiye, 2013:92). Global İletişim Ajansı Edelman tarafından 11 ülkede yapılan "8095" Araştırmasının sonuçlarına göre Y Kuşağı gelecek adına önemli özellikleri taşımaktadır. Araştırma sonuçlarına göre Y Kuşağının gelecek adına sahip olduğu stratejik önem aşağıdaki gibi özetlenebilir ( Edelman,2013:43).

- Dünyadaki 7 milyar nüfusun 1,8 milyarını Y Kuşağı oluşturmaktadır. Bu dünyadaki en geniş nesil.

- 2025 yılı itibariyle dünya çalışan nüfusunun yüzde 75'ini oluşturması bekleniyor.

- 2018 y1lı itibariyle bir önceki nesilden daha fazla harcama gücüne sahip olacaklar.

- Ekonomik belirsizlikler, 11 Eylül, Tsunami, İnternet, Akıllı telefonlar ve Facebook hayatlarını değiştiren etkenler.

- Tarihteki en fazla çeşitliliğe sahip ve eğitimli nesil.

Mc Queen'e göre Y Kuşağı her ne kadar karakteristik özellikleri ile coğrafi ve kültürel olarak değişim gösterse de, bir çok ortak özelliğe sahiptir. Queen Y Kuşağı ile ilgili şu tanımlamayı yapmıştır (2011):

“ Bu kuşak genellikle teknoloji bağımlısı, kendine aşırı güvenen, haddini bilmez, kendinden çok emin ve saygısız olarak tanımlanıyor. Bu tür eleştiriler bu grubun bir bölümü için geçerli olabilir. Hepsi için değil. Y Kuşă̆l çok olumlu özellikler de taşımaktadır. Onlar, esnek, adaptasyon yeteneği yüksek, iyi eğitimli, sosyal statü sahibi ve pek çok yönden oldukça korkusuzlar. Haklarını biliyorlar, otoriteyi sorguluyorlar ve ilgisiz veya adaletsiz olan ile ilgileniyorlar. Tüketiciler olarak ise, Y Kuşağı deneyim odakll, seçici, marka bilinçli, birazcık vefasız ve fiyat duyarlıdır."

Conento'nun gerçekleştirdiği araştırma sonucuna göre Y Kuşağı kendi içinde dört farklı yaş grubuna ayrılmaktadır. Bu yaş grupları ve sahip oldukları özellikler şöyledir (Tufur,2013:34): 
Tablo 5. Y Kuşağının Yaşam Basamakları

\begin{tabular}{|c|c|c|c|}
\hline Basamak & Yaş & Dönem & Özellikleri \\
\hline 1 & $18-21$ & Okul Yılları & Bireyci, başarı odaklı \\
\hline 2 & $22-25$ & $\begin{array}{c}\text { Okul yıllarının sonu iş bulmam ve } \\
\text { tutunma telaşı }\end{array}$ & İdealist, başarı odaklı \\
\hline 3 & $26-29$ & $\begin{array}{c}\text { Çalışma hayatı, evli veya evlilik } \\
\text { hazırlıkları yaparken }\end{array}$ & Bireyci \\
\hline 4 & $30-35$ & Çalışma hayatı, evli - çocuklu hayatı & Genç Aile \\
\hline
\end{tabular}

\section{Y KUŞAĞININ ÖZELLIKLERİ}

Çocukluk yıllarını 80’lerde, gençlik yıllarını 90'larda yaşayan Y Kuşağı çok kanallı televizyonlarla büyümüş ve internetle genç yaşta tanışarak hemen adapte olmuşlardır. Çatalkaya Y kuşağının öne çıkan özellikleri arasında tatminsizliğin geldiğini söylemiştir.

Y kuşağının başlıca özelliklerini: kolay tatmin olmama, sorumluluk almaya hevesli olma, rahatına düşkün, yüksek otorite karşısında rahatsız olma şeklinde tanımlayan Çatalkaya Y kuşağının en zayıf noktasının konsantrasyon olduğunu belirtmiştir (Çatalkaya,2013). (Baltaş,2011:54) Y kuşağının bu özelliği ile ilgili ‘... dikkatlerini toplamakta zorlanmaları, çabuk dağılmaları ve zamanlarını iyi yönetememeleri..'ni bu kuşağın en zayıf noktası olarak yorumlamıştır.

İçinde Türkiye'nin de yer aldığı 11 ülkede düzenlenen ve Y kuşağını değerlendiren “8095” adlı araştırmasında Edelman'ın raporunda Y kuşağının üç önemli trende önderlik yaptığı belirtilmiştir ( Edelman, 2013:51):

- Kentleşme: 2050 yılın itibariyle insan nüfusunun \% 70’i kentlerde yaşıyor olacak. Bu da Y kuşağının kırsal değil tam bir kent kültürüne sahip olması anlamına gelmektedir.

- Deneyim: Y kuşağı satın alma alışkanlıklarında yaşadığı deneyime çok ama çok önem veriyor.

- Ebeveyn rolü: Kadınların daha çok para kazandığı, erkeklerin ise ev işlerine daha çok yardımcı olduğu bir nesil ile karşı karşıyayız. Roller değişiyor.

Johnson Controls tarafından 2010 yılında yapılan araştırmaya göre Y kuşağı en belirgin nitelikleri arasında; çevreye duyarlı olma, sürdürülebilirliğe önem verme, esnek ve mobil yaşam tarzını benimseme, iş birliğine açık ve alışılageldik sınırlara bağlı kalmama yer almaktadır (Usta,2012:39). 
Y kuşağını önceki kuşak olan X kuşağından ayıran en önemli özellik teknoloji ile daha fazla ilgili olmalarıdır. Kılıç Y kuşağının X kuşağından farklarını şöyle açıklamıştır ( Kılıç,2012:14):

Tablo 6. Y Kuşağının X Kuşağından Farkları

\begin{tabular}{|l|}
\hline İnternet ve çok kanallı televizyon ile birlikte büyüdüler \\
\hline Mobil ya da yüzyüze görüşme haricinde sanal görüşmeyi de tercih edebiliyorlar \\
\hline Yokluk bilgileri yoktur, daha sabırsızdırlar \\
\hline Sadakat duyguları daha zayıftır \\
\hline Kendine güven duyguları daha yüksektir \\
\hline Hangi şirkette çalıştıkları değil, şirketin sağladı̆̆ı imkânlar onlar için daha önemlidir \\
\hline Rahatlarına daha fazla düşkündürler \\
\hline Daha hırslılar \\
\hline
\end{tabular}

Uluslar arası araştırma şirketi Ipsos'un Kalitatif Araştırmalar biriminin gerçekleştirdiği 'Ayna: Onlar Y Kuşağı' isimli kalitatif araştırma Y kuşağını en belirgin özelliklerini on iki madde altında raporlamıştır (Ipsos, 2013):

3.1 Farklılık: Her zaman farklı olanı arıyorlar. Bu, kıyafetlerinde de, gittikleri mekânlarda da, internet paylaşımlarında da kendini göstermektedir. Yeniliğe, keşfetmeye daha açık bir jenerasyon olarak ayrışmak ve farklılaşmak önemli bir özellik.

3.2 Esneklik: Kendini ifade edebileceği ortamlarda olmak istiyor. Belirgin ve sert kurallardan, çerçevesi belli şartlardan kaçıyorlar.

3.3 Hedonism: Önceki kuşağa göre kendi mutluluklarını birçok şeyden daha öncelikli görmektedirler. Farklı deneyimler yaşamak, iyi vakit geçirmek, hayattan zevk almak onlar için önemli.

3.4 Teknoloji: Bu kuşağın en ayırt edici özelliği teknolojiye olan düşkünlüğüdür. İnternet çağında büyümüş bir kuşak, en önemli bilgi edinme kaynakları internet. Uzun, derinlikli, içine dalınıp araştırılacak bilgi kaynakları değil, kolay ulaşabilecekleri küçük bilgi paketleri arıyorlar.

3.5 Multitasking: Hem hayatın hızlanması, hem de teknoloji onları multitasking ( çok yönlü) hale getirmiştir. Buna bağlı olarak dikkat süreleri çok kısa ve dikkatlerini çekmek çok zor.

3.6 Deneyim Paylaşımı: Y kuşağı çok belirgin bir deneyim paylaşım kültürüne sahiptir. Hem dijital ortamda hem de dışarıda kendi deneyimleri üzerinde fikir paylaşmayı 
seviyorlar. Bir karar verirken de geleneksel pazarlama kanalları yerine, arkadaş fikirlerine, forumlardaki yorumlara daha çok dikkat ediyorlar.

3.7 Aile: Geçmiş kuşaklardan farklı olsa da Türkiye'deki Y kuşağının geleneksel bir yanı var. Aile bu kişiler için önemini korumaktadır. Aileyi hem bir role model olarak alıyorlar, hem de bir destek ünitesi olarak görüyorlar. Aileden bekledikleri başka bir şey ise eşitlikçi ve özgür bir ilişki.

3.8 Dünya ile İlişki: Teknolojinin de gelişmesi ile beraber dünyaya daha çabuk entegre olan kuşak küresel eğilimlere de açık, ancak Türklüğü ve yerelliği ile ilgili değerlere de sahip çıkmaktadır.

3.9 Markalar: Kişisel kimliklerini ortaya koymak ve çevrelerinden farklılaşmak için markaları kullanıyorlar. Markalar ile duygusal bir ilişki kuruyorlar, beğendikleri markaların ürünlerini kendilerine göre iyi olan bir fiyata aldıklarında kendilerini 'başarılı' hissediyorlar.

3.10 Hız: Hız Y kuşağının hayatını en iyi anlatan temalardan biridir. Hayat onlara göre hızlı akmaktadır, buna göre zevkleri, ilgi alanları önceki kuşaklara göre daha hızlı değişebiliyor.

3.11Sadakat: Düşük sadakat sadece markalara yönelik değil, aşk ilişkilerinde ve çalıştıkları işte de ortaya çıkmaktadır. Hem etraflarında çok alternatif olması hem de kısa vadede tatminlerini önemsemeleri onları çok hızlı fikir değiştirmeye itmekte ve bu durum onların sadâkatını azaltmaktadır.

3.12 Tanınırlık: Başarı bu kuşak için önemlidir ama bu başarının görünür olması daha önemlidir. Yaptıkları işte fark edilmek ve takdir edilmek isteyen kuşak bireyleri daha fazla "tebrikler, aferin" duymak ve daha fazla şımartılmayı istemektedir.

Y kuşağı tüketim alışkanlıklarında da kendisini fark ettirmektedir. Youth Research tarafından Türkiye'de yapılan araştırmada $\mathrm{Y}$ kuşağının tüketim alışkanlıklarında $\mathrm{X}$ kuşağından daha farklı özelliklere sahip olduğu ortaya çıkmıştır. Araştırma bulgularına göre X kuşağı müşterisi markaya 'İşimi görsün, ucuz olsun’ şeklinde bakarken, Y kuşağı müşterisi ' Seveyim pahalı da olabilir' şeklinde bakmaktadır (Youth Research,2013).

MTV, Nickelodeon, VH1 gibi küresel eğlence içeriği ile tanınan Viacom tüm dünyadaki izleyicilerini daha yakından tanımak ve onların değişen taleplerini görmek için gerçekleştirdiği Next Normal adlı araştırmasında Y Kuşağının gündeminde yer alan konuları tespit etmiştir. Araştırma sonuçlarına göre Y kuşağı günümüzde en çok ekonomik sorunlarla 
ilgilenmektedir. Katılımcıların \% 68'i küresel ekonomik krizden kitlesel olarak etkilendiğini belirtirken, terör korkusunun gündemlerinin ikinci sırasında yer aldığını söylemiştir. Kuşağın gündeminde üçüncü sırada doğal felaketler, dördüncü sırada teknoloji, beşinci sırada ise sosyal, siyasal ve kültürel olaylar yer almaktadır ( Bloomberg Businessweek Türkiye, 2013:65-66).

Kuşaklar aynı dönemlerde de yaşasa yaşadıkları coğrafyalardan etkilenerek özelliklerini farklılaştırabilmektedir. Yaşadıkları ülkenin coğrafi, ekonomik koşullarından etkilenen bireyler bu çevresel koşulların onlara olan etkileri sonucunda daha farklı hüviyetlere sahip olabilmektedirler. Edelman Türkiye 8095 Araştırması Türkiye'de yaşayan Y kuşağı temsilcilerinin kendi işlerini kurma konusunda daha azimli olduklarını göstermiştir. Araştırmaya göre Türkiye'de yaşayan Y kuşağı Avustralya, Brezilya, Kanada, Çin, Fransa, Almanya, Hindistan, Arap Emirlikleri, İngiltere ve ABD'de yaşayan Y kuşağı bireylerinden daha yüksek oranda kendi işini kurma isteği taşımaktadır. Araştırma sonucunda Türkiye'de yaşayan bu kuşağın üyeleri ev sahibi olmak ve aile kurma konusunda da daha hızlı ve azimli oldukları ortaya çıkmıştır. Tablo 7'de belirtilen kuşağın yaşam ideallerine yönelik coğrafi analiz Türkiye'de yaşayan kuşak temsilcilerinin bazı konularda dünyadaki akranlarına göre daha hızlı ve agresif bir ruh hali içinde olduğunu göstermektedir.

Tablo 7. Dünyada ve Türkiye'de Yaşayan Y Kuşağının İdealleri ( Edelman 8095 Araştırması)

\begin{tabular}{|l|c|c|}
\hline & Dünya Oranı (\%) & Türkiye Oranı (\%) \\
\hline $\begin{array}{l}\text { Kişisel tutkuları ile örtüşen bir iş } \\
\text { yapmak }\end{array}$ & $79 \%$ & 86 \\
\hline Ev sahibi olmak & 78 & 82 \\
\hline Aile kurmak, evlenmek & 72 & 80 \\
\hline
\end{tabular}




\section{SOSYAL MEDYA VE SOSYAL AĞLAR}

Sosyal medya, salt okunur halden etkileşimli bir sanal dünyaya çeviren web 2.0 akımının gelişmesiyle birlikte amacı bilgi alışverişi yapmak, çalıştıkları sektörlerden veya ilgilendikleri alanlardan, aynı fikri paylaştıkları insanlarla tanışmak olan kullanıcılar, kurulan sosyal ağ siteleri ile internet üzerinde toplanmaya başladı. Bu sitelerde oluşan ilişkiler gelişerek, gerçek hayatta da buluşan insanların oluştukları sosyal medyayı ortaya çıkarmıştır. Günümüzde sosyal medya, içinde şirket yöneticilerinden danışmanlara, internet liderlerinden reklamcılara, blog yazarlarından gazetecilere kadar geniş bir kitlenin fikir alışverişi yaptığı bir ortam sunmaktadır (Bozkurt,2010:50).

Evans'a göre sosyal medya, enformasyonun demokratize edilmesi, içerik okuyucusu konumunda olan bireylerin içerik yayınlayıcısı haline dönüşmeleridir (2008:34). Solis sosyal medyayı beş aşamada tanımlamıştır (2011:12):

-Medyanın sosyalleşmesi için kullanılan bir platform,

-Kişilerarası iletişimi kolaylaştıran çevrim içi araçları,

-Bireylerin çevreleriyle bağ kurmasını sağlayan,

-İşbirliği sağlayan,

-Etkinin yayılımını kolaylaştıran bir firsat ve ayrıcalık olarak nitelendirmektedir.

Bireylere sınırlı bir sistem içerisinde herkese açık ya da yarı açık profil oluşturmaya izin veren, bağlantıda bulunduğu diğer kullanıcıların listesini açıkça ortaya koyan ve sistem içerisinde diğerlerinin bağlantıda bulunduğu kişilerin listesini gösteren elektronik tabanlı hizmetlerin tümü sosyal ağlar olarak tanımlanmaktadır (Boyd ve Ellison,2007:215).

Tablo 8. Sosyal Medya Ağlarının Gelişimi (Kara:2012:119)

\begin{tabular}{|c|c|}
\hline Kuruluş Yılı & Sosyal Ă \\
\hline 2002 & LinkedIn \\
\hline 2003 & My Space, Hi5 \\
\hline 2004 & Facebook \\
\hline 2005 & You Tube, Bebo \\
\hline 2006 & Twitter \\
\hline 2007 & Tumbir, Friendfeed \\
\hline 2008 & Google, Buzz \\
\hline 2010 & Diaspora \\
\hline 2011 & Google + \\
\hline
\end{tabular}


2004 yılında Mark Zuckerberg ve ekibi tarafından kurulan ve dünyanın en çok rağbet gören sosyal medya ağlarından biri olan Facebook Hall ve Rosenberg'e göre küçük işletme sahiplerinin ağlarını genişletmesine, potansiyel müşteri ve arkadaşlarla iletişim kurmaya, blog gönderileri, resimler ve videolar yoluyla işletme bilgilerini paylaşmaya imkân vermektedir (Akar,2010:35).

Facebook 5,1 milyar dolarlık geliri ile 2013 yılında Fortune tarafından dünyanın en önemli 500 şirketi arasında girerek 482.inci sırada yer almıştır (Atasoy,2013). Dünyanın en fazla kullanılan sosyal medya ağı olan Facebook bir milyarın üzerinde kullanıcısı ile sadece dünyada değil Türkiye'nin de en çok ziyaret edilen sosyal medya ağı olarak tarihe geçmiştir (SilverPop,2013).

\section{ARAŞTIRMA}

5.1 Araştırmanın Amacı ve Yöntemi: $\mathrm{Bu}$ araştırmada $\mathrm{Y}$ kuşağının dünyanın en popüler sosyal medya ağı olan Facebook'u kullanma alışkanlıkları araştırılmıştır. Yüz yüze görüşme tekniği ile 378 kişiye uygulanan ankette Y kuşağının Facebook kullanım alışkanlarının yaşa göre farklılık gösterip göstermediği analiz edilmiştir. Araştırmada ayrıca $Y$ kuşağının sosyal medya ağını kullanma alışkanlıkları içinde Facebook'u geleneksel medyaya göre daha fazla kullanma düzeyleri ve kuşağın Facebook’un bağımlılık yarattığına dair yargı hakkında ki düşünceleri analiz edilmiştir. Araştırmada aşağıdaki sorulara yanıt aranmıştır:

- Y kuşağının Facebook kullanım alışkanlıkları nedir?

- Y kuşağı Facebook adlı sosyal medya ağını geleneksel medyanın mecralarından daha fazla kullanıyor mu?

- Y Kuşağı 'Facebook'un bağımlılık yarattığına' dair görüşe katılıyor mu? Bu durum kuşak bireylerinin yaş ve cinsiyetine göre değişiyor mu?

\subsection{Güvenilirlik Analizi}

Y Kuşağının Facebook kullanım alışkanlıklarını ölçmek amacıyla hazırlanan ankette beşli likert tipi ölçeklenmiş 20 maddelik ölçek 378 kişiye uygulanmıştır. Tamamen katılıyorum 5, katılıyorum 4, kararsızım 3, katılmıyorum 2 ve hiç katılmıyorum 1 puan olacak şekilde ölçek maddeleri puanlanmıştır. Ölçeğin faktöriyel yapısını belirlemek ve aynı zamanda geçerlik çalışması için toplanan verilere açıklayıcı faktör analizi yapılmış ve sonuçları Tablo 9' da gösterilmiştir. 
Tablo 9: Geçerlilik Analizleri

\begin{tabular}{|c|c|c|c|c|c|c|}
\hline \multirow{2}{*}{ Faktör } & \multicolumn{3}{|c|}{ Öz değerler } & \multicolumn{3}{|c|}{$\begin{array}{l}\text { Varimax döndürme sonucu ( } 2 \text { faktörle } \\
\text { sınırlandırılmış) Faktör yüklerinin } \\
\text { kareleri toplamı }\end{array}$} \\
\hline & Toplam & $\begin{array}{l}\text { Açıklanan } \\
\text { Varyans \% }\end{array}$ & $\begin{array}{c}\text { Birikimli } \\
\text { Varyans \% }\end{array}$ & Toplam & $\begin{array}{l}\text { Açıklanan } \\
\text { Varyans \% }\end{array}$ & $\begin{array}{c}\text { Birikimli } \\
\text { Varyans \% }\end{array}$ \\
\hline 1 & 8,939 & 44,694 & 44,694 & 4,668 & 23,342 & 23,342 \\
\hline 2 & 1,433 & 7,164 & 51,858 & 3,045 & 15,224 & 38,566 \\
\hline 3 & 1,155 & 5,774 & 57,632 & 2,471 & 12,355 & 50,921 \\
\hline 4 & 1,083 & 5,413 & 63,045 & 2,258 & 11,291 & 62,212 \\
\hline 5 & 1,005 & 5,025 & 68,070 & 1,172 & 5,858 & 68,070 \\
\hline \multicolumn{7}{|c|}{ Kaiser-Meyer-Olkin örneklem yeterliliği:0.876 } \\
\hline Bar & $\overline{c e s}$ & 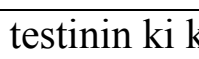 & leŏe & 3,746 & $\mathrm{~d}=190 \mathrm{p}$ & \\
\hline
\end{tabular}

Kaiser-Meyer-Olkin istatistiğinin 0,876 olduğu ve bu istatistiğin 0.50 den büyük çıkması ise veriler için örneklem sayısının yeterli olduğunun bir göstergesidir (Kalaycı, 2005, s:322). Oran ne kadar yüksek ise veri seti faktör analizi yapmak için o kadar iyidir. Bartlett küresellik testi sonuçları da verilerin faktör analizi için uygunluğunu test eder. Dolayısıyla bu veriler için verilerin faktör analizine uygun olduğu gözlenmiştir $(\mathrm{p}<0.05)$.

Açıklanan toplam varyans tablosu incelendiğinde 20 maddelik ölçekte 1 özdeğerinden büyük 5 faktörün bulunduğu ve bu 5 faktörlü ölçme aracı ile ölçülen özelliğin \%68'inin ölçüldüğü gözlenmiştir. Ancak özdeğerler veya öz değerlere ilişkin faktör grafiği (scree plot) sonuçları incelendiğinde belirgin olarak 20 maddenin tek faktör altında toplandığı gözlenmiştir. Özdeğerlere ilişskin grafik Şekil 1'de gösterilmiştir. 


\section{Scree Plot}

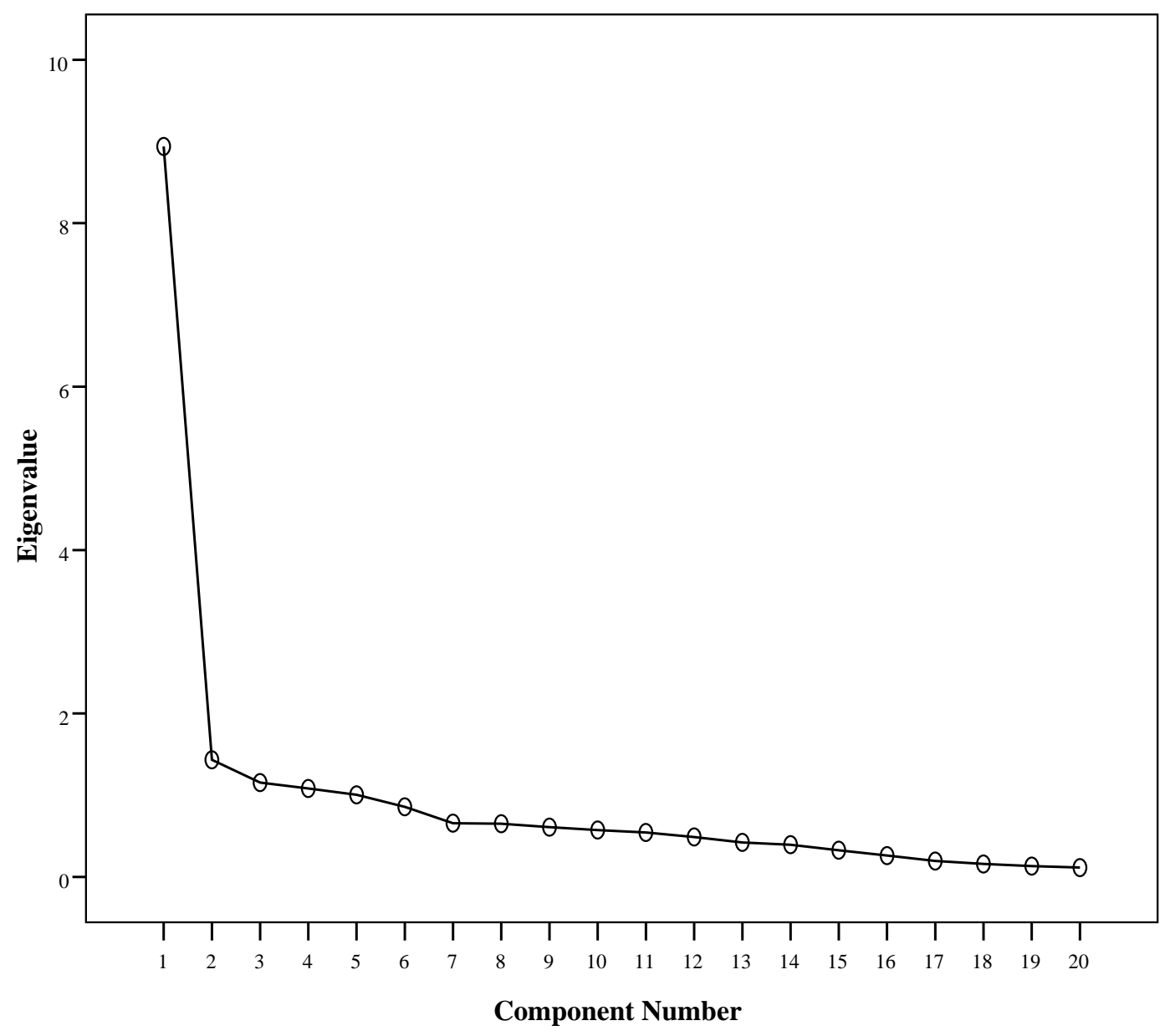

Şekil 1: Öz değerlere ilişkin faktör grafiği

Yamaç birikinti grafiğinde de tek faktörlü olduğu gözlenen veriler tek faktörle sınırlandırılıp açıklayıcı faktör analizi tekrarlanmıştır Tek faktörlü faktör analizinde ölçek maddelerinin sıralanmış faktör yükleri Tablo 10’ da gösterilmiştir. 
Tablo 10: Ölçek Maddelerinin Faktör Yükleri

\begin{tabular}{|c|c|}
\hline & Faktör 1 \\
\hline 22.Facebook'suz bir hayat düşünemiyorum & 0,830 \\
\hline $\begin{array}{l}\text { 20.Arkadaşlarımla telefonla konuşmak yerine Facebook aracıllğ } \mathrm{ile} \text { chat } \\
\text { yaparak iletişim kurmak beni daha fazla mutlu ediyor }\end{array}$ & 0,816 \\
\hline $\begin{array}{l}\text { 21.Facebook'a girmediğim zamanlar hayatımda bir şeylerin eksik olduğunu } \\
\text { hissediyorum }\end{array}$ & 0,815 \\
\hline $\begin{array}{l}\text { 13.Radyodan müzik dinlemek yerine Facebook aracılığı ile müzik dinlemeyi } \\
\text { tercih ediyorum }\end{array}$ & 0,808 \\
\hline $\begin{array}{l}\text { 18.Hakkımda ki bir bilgiyi / gelişmeyi arkadaşlarıma yüz yüze görüşmek } \\
\text { yerine söylemek yerine Facebook aracıllı̆̆ ile söylemeyi tercih ederim }\end{array}$ & 0,795 \\
\hline 16.Facebook benim için en önemli haber alma araçlarından biri & 0,746 \\
\hline $\begin{array}{l}\text { 17.Hakkımda ki bir bilgiyi / gelişmeyi arkadaşlarıma telefon ile söylemek } \\
\text { yerine Facebook aracıllı̆ı ile söylemeyi tercih ederim }\end{array}$ & 0,732 \\
\hline 19.Facebook'ta farklı bir dünya buluyorum & 0,708 \\
\hline $\begin{array}{l}\text { 8.Gündemdeki haberleri gazeteden takip etmek yerine Facebook’taki } \\
\text { paylaşımlardan öğrenmeyi tercih ediyorum }\end{array}$ & 0,695 \\
\hline 5.Facebookta geçirdiğim zaman radyo dinlediğim zamandan daha fazla & 0,693 \\
\hline $\begin{array}{l}\text { 14.Facebook üzerinde yer alan oyunları oynayarak zaman geçirmek hoşuma } \\
\text { gidiyor }\end{array}$ & 0,676 \\
\hline $\begin{array}{l}\text { 9.Arkadaşlarımın ilgisini çeken bir haber veya video ilgimi çekerse bende o } \\
\text { haberi arkadaşlarımla paylaşırım }\end{array}$ & 0,626 \\
\hline $\begin{array}{l}\text { 15. Arkadaşlarımın önerdiği konser ve etkinlik haber ve önerilerini dikkate } \\
\text { alıyor ve bu önerilere uyarak farklı etkinliklere katılıyorum }\end{array}$ & 0,621 \\
\hline $\begin{array}{l}\text { 10.Dinlemekten zevk aldığım, sevdiğim bir şarkıyı mutlaka Facebook’ta } \\
\text { paylaşırım }\end{array}$ & 0,614 \\
\hline $\begin{array}{l}\text { 12.Sevdiğim radyo ve tv kanallarının Facebook sayfalarını mutlaka ziyaret } \\
\text { ediyorum }\end{array}$ & 0,605 \\
\hline 11.Facebook'ta bulunan sanatçı hayran sayfalarını sık sık ziyaret ediyorum & 0,604 \\
\hline $\begin{array}{l}\text { 6.Facebook’ta geçirdiğim zaman televizyon izlerken geçirdiğim zamandan } \\
\text { daha fazla }\end{array}$ & 0,546 \\
\hline $\begin{array}{l}\text { 4.Facebook'ta arkadaşımın satın alarak fotoğrafını paylaştığı bir ürün ilgimi } \\
\text { çekerse o ürünü bende satın alırım }\end{array}$ & 0,472 \\
\hline 7.Cep telefonumdan mutlaka Facebook sayfamı açıyorum & 0,423 \\
\hline 23. Facebook benim için haber almaktan çok & 0,184 \\
\hline
\end{tabular}

Faktör yükleri incelendiğinde 0,30 değerinden düşük faktör yüküne sahip 23. maddenin olduğu gözlenmiş ve bu madde ölçekten çıkarılmıştır. Bu madde çıkarılıp tekrar 
faktör analizi yapıldığında 19 maddelik ölçeğin faktör yüklerinin 0.402 ile 0.829 arasında değiștiği gözlemlenmiştir. Dolayısıyla faktör yük değerleri bakımından (faktör yükü 0,30 değerinden düşük bir madde olmadığından) ölçek 19 madde olarak değerlendirilmiştir. Uygulamalarda az sayıda madde elemesi için faktör yük değerinin 0.30'a olduğu görülmektedir (Büyüköztürk,2002:29).

Ölçeğin güvenirliğine Cronbach Alpha katsayısı ile bakılmıştır. 19 maddelik ölçeğin Cronbach Alpha katsayısı 0.933 olarak yüksek bir güvenirlik elde edilmiştir. Güvenirlik katsayısı, 0 ile +1 arasında değişkenlik gösterir. Güvenirlik katsayısının 1'e yakın değerler alması güvenirliğin yüksek olduğu, maddeler arasında iç tutarlılığın yüksek olduğu anlamına gelir ve istendiktir. Ölçek maddelerinin madde geçerlik katsayısı olarak da bilenen maddetoplam korelasyonları incelendiğinde sonuçları Tablo 11'de gösterilmiştir.

Tablo 11: Madde Toplam Korelasyonları

\begin{tabular}{|l|c|}
\hline & $\begin{array}{c}\text { Madde } \\
\text { Toplam } \\
\text { Korelasyonu }\end{array}$ \\
\hline $\begin{array}{l}\text { 4.Facebook'ta arkadaşımın satın alarak fotoğrafını paylaştı̆̆ı bir ürün ilgimi çekerse o } \\
\text { ürünü bende satın alırım }\end{array}$ & 0,433 \\
\hline 5.Facebookta geçirdiğim zaman radyo dinlediğim zamandan daha fazla & 0,642 \\
\hline 6.Facebook'ta geçirdiğim zaman televizyon izlerken geçirdiğim zamandan daha fazla & 0,482 \\
\hline 7.Cep telefonumdan mutlaka Facebook sayfamı açıyorum & 0,357 \\
\hline $\begin{array}{l}\text { 8.Gündemdeki haberleri gazeteden takip etmek yerine Facebook'taki paylaşımlardan } \\
\text { öğrenmeyi tercih ediyorum }\end{array}$ & 0,653 \\
\hline $\begin{array}{l}\text { 9.Arkadaşlarımın ilgisini çeken bir haber veya video ilgimi çekerse bende o haberi } \\
\text { arkadaşlarımla paylaşıım }\end{array}$ & 0,608 \\
\hline 10.Dinlemekten zevk aldığım, sevdiğim bir şarkıyı mutlaka Facebook’ta paylaşırım & 0,567 \\
\hline 11.Facebook'ta bulunan sanatçı hayran sayfalarını sık sık ziyaret ediyorum & 0,541 \\
\hline 12.Sevdiğim radyo ve tv kanallarının Facebook sayfalarını mutlaka ziyaret ediyorum & 0,552 \\
\hline $\begin{array}{l}\text { 13.Radyodan müzik dinlemek yerine Facebook aracılığı ile müzik dinlemeyi tercih } \\
\text { ediyorum }\end{array}$ & 0,767 \\
\hline 14.Facebook üzerinde yer alan oyunları oynayarak zaman geçirmek hoşuma gidiyor & 0,612 \\
\hline $\begin{array}{l}\text { 15. Arkadaşlarımın önerdiği konser ve etkinlik haber ve önerilerini dikkate alıyor ve } \\
\text { bu önerilere uyarak farklı etkinliklere katıllyorum }\end{array}$ & 0,570 \\
\hline 16.Facebook benim için en önemli haber alma araçlarından biri & 0,712 \\
\hline $\begin{array}{l}\text { 17.Hakkımda ki bir bilgiyi / gelişmeyi arkadaşlarıma telefon ile söylemek yerine } \\
\text { Facebook aracılığı ile söylemeyi tercih ederim }\end{array}$ & 0,684 \\
\hline $\begin{array}{l}\text { 18.Hakkımda ki bir bilgiyi / gelişmeyi arkadaşlarıma yüz yüze görüşmek yerine } \\
\text { söylemek yerine Facebook aracıll̆ğı ile söylemeyi tercih ederim }\end{array}$ & 0,751 \\
\hline 19.Facebook'ta farklı bir dünya buluyorum & 0,652 \\
\hline $\begin{array}{l}\text { 20.Arkadaşlarımla telefonla konuşmak yerine Facebook aracıllı̆ı ile chat yaparak } \\
\text { iletişim kurmak beni daha fazla mutlu ediyor }\end{array}$ & 0,778 \\
\hline $\begin{array}{l}\text { 21.Facebook'a girmediğim zamanlar hayatımda bir şeylerin eksik olduğunu } \\
\text { hissediyorum }\end{array}$ & 0,773 \\
\hline 22.Facebook'suz bir hayat düşünemiyorum & 0,790 \\
\hline
\end{tabular}


Madde toplam korelasyonları incelendiğinde 0,357 ile 0,790 arasında değiştiği gözlenmiştir. Madde geçerlik katsayısı olarak da değerlendirilen madde toplam korelasyonlarının 0,30 değerinden yüksek bulunmuştur.

\subsection{Bulgular}

Araştırmaya katılan Y kuşağına ait bireylerin yaşlarına göre yüzde frekans dağılımları Tablo 12'de gösterilmiştir.

Tablo 12: Araştırmaya Katılanların Yaş Frekans Dağılımları

\begin{tabular}{|c|c|c|c|c|}
\hline & & Kişi sayısı & $\%$ & Geçerli \% \\
\hline \multirow{15}{*}{ Yaş } & 17 & 3 & 0,8 & 0,8 \\
\hline & 19 & 6 & 1,6 & 1,6 \\
\hline & 20 & 15 & 4,0 & 4,1 \\
\hline & 21 & 42 & 11,1 & 11,4 \\
\hline & 22 & 81 & 21,4 & 22,0 \\
\hline & 23 & 78 & 20,6 & 21,1 \\
\hline & 24 & 48 & 12,7 & 13,0 \\
\hline & 25 & 33 & 8,7 & 8,9 \\
\hline & 26 & 30 & 7,9 & 8,1 \\
\hline & 27 & 12 & 3,2 & 3,3 \\
\hline & 28 & 12 & 3,2 & 3,3 \\
\hline & 29 & 3 & 0,8 & 0,8 \\
\hline & 32 & 3 & 0,8 & 0,8 \\
\hline & 33 & 3 & 0,8 & 0,8 \\
\hline & Toplam & 369 & 97,6 & 100,0 \\
\hline Yanit vermeyen & & 9 & 2,4 & \\
\hline \multicolumn{2}{|l|}{ Toplam } & 378 & 100,0 & \\
\hline
\end{tabular}

Araştırmaya katılan gençlerin cinsiyetlerine göre yüzde frekans dağılımları Tablo 13 'de gösterilmiştir.

Tablo 13: Araştırmaya Katılanların Cinsiyet Frekansları

\begin{tabular}{|l|l|c|c|c|}
\hline \multicolumn{2}{|c|}{} & Kişi sayısı & $\%$ & Geçerli \% \\
\hline \multirow{3}{*}{ Cinsiyet } & Erkek & 249 & 65,9 & 68,0 \\
\cline { 2 - 5 } & Kadın & 117 & 31,0 & 32,0 \\
\cline { 2 - 5 } & Toplam & 366 & 96,8 & 100,0 \\
\hline $\begin{array}{l}\text { Yanıt } \\
\text { vermeyen }\end{array}$ & 12 & 3,2 & \\
\hline \multicolumn{2}{|l|}{ Toplam } & 378 & 100,0 & \\
\hline
\end{tabular}


Araştırmaya katılanların Facebook hesabı olup olmamasına göre yüzde frekans dağılımları Tablo 14'de gösterilmiştir.

Tablo 14: Araştırmaya Katılanların Facebook Hesap Sahipliği Oranı

\begin{tabular}{|l|l|c|c|c|}
\hline \multicolumn{2}{|c|}{} & Kişi sayıs1 & $\%$ & Geçerli \% \\
\hline \multirow{3}{*}{ 1.Facebook Hesabınız Var mı? } & Evet & 369 & 97,6 & 99,2 \\
\cline { 2 - 5 } & Hayır & 3 & 0,8 & 0,8 \\
\cline { 2 - 5 } & Toplam & 372 & 98,4 & 100,0 \\
\hline Yanıt vermeyen & & 6 & 1,6 & \\
\hline \multicolumn{2}{|l|}{ Toplam } & 378 & 100,0 & \\
\hline
\end{tabular}

Araştırmaya katılan gençlerin Facebook'ta geçirdikleri zamanın yüzde frekans dağglımları Tablo 15'de gösterilmiştir.

Tablo 15: Facebook'ta Geçirilen Süre

\begin{tabular}{|l|c|c|c|c|}
\hline \multicolumn{2}{|c|}{} & Kişi sayıs1 & $\%$ & Geçerli \% \\
\hline \multirow{4}{*}{$\begin{array}{l}\text { 3.Günde kaç saatinizi } \\
\text { Facebook'ta } \\
\text { geçiriyorsunuz? }\end{array}$} & 1 saat & 84 & 22,2 & 22,6 \\
\cline { 2 - 5 } & 2 saat & 84 & 22,2 & 22,6 \\
\cline { 2 - 5 } & 3 saat & 105 & 27,8 & 28,2 \\
\cline { 2 - 5 } & 4 saat & 54 & 14,3 & 14,5 \\
\cline { 2 - 5 } & 4 saat ve üzeri & 45 & 11,9 & 12,1 \\
\cline { 2 - 5 } & Toplam & 372 & 98,4 & 100,0 \\
\hline Yanıt vermeyen & 6 & 1,6 & \\
\hline \multicolumn{2}{|l|}{ Toplam } & 378 & 100,0 & \\
\hline
\end{tabular}

Araştırmaya katılan gençlerin Facebook hesaplarının aktif olma sürelerinin yüzde frekans dağılımları Tablo 16'da gösterilmiştir.

Tablo 16: Facebook’u Kullanma Süresi

\begin{tabular}{|l|c|c|c|c|}
\hline \multicolumn{2}{|c|}{} & $\begin{array}{c}\text { Kişi } \\
\text { sayıs }\end{array}$ & $\%$ & $\begin{array}{c}\text { Geçerli } \\
\%\end{array}$ \\
\hline \multirow{4}{*}{$\begin{array}{l}\text { 2.Facebook Hesabınız varsa } \\
\text { bu hesap kaç yıldır aktif? }\end{array}$} & 1 yıldan az & 9 & 2,4 & 2,4 \\
\cline { 2 - 5 } & $1-2$ y1l & 12 & 3,2 & 3,2 \\
\cline { 2 - 5 } & $2-4$ yıl & 132 & 34,9 & 35,2 \\
\cline { 2 - 5 } & 4 yildan fazla & 222 & 58,7 & 59,2 \\
\cline { 2 - 5 } & Toplam & 375 & 99,2 & 100,0 \\
\hline Yanıt vermeyen & & 3 & 0,8 & \\
\hline Toplam & 378 & 100,0 & \\
\hline
\end{tabular}

Araştırmaya katılanların Facebook ile ilgili görüşlerinin yüzde frekans dağılımları Tablo 17'de gösterilmiştir. 
Tablo 17: Facebook Ağına Katılan Y Kuşağının Sosyal A ğ ile ilgili Görüşleri

\begin{tabular}{|c|c|c|c|c|c|}
\hline & 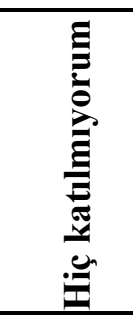 & 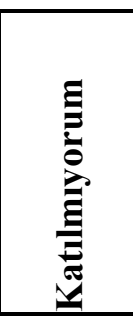 & 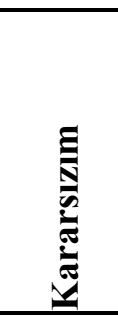 & 苞 & 焉 \\
\hline & $\%$ & $\%$ & $\%$ & $\%$ & $\%$ \\
\hline $\begin{array}{l}\text { 4.Facebook'ta arkadaşımın satın alarak fotoğrafını } \\
\text { paylaştığı bir ürün ilgimi çekerse o ürünü bende satın } \\
\text { alırım }\end{array}$ & $27,0 \%$ & $24,6 \%$ & $23,8 \%$ & $15,1 \%$ & $9,5 \%$ \\
\hline $\begin{array}{l}\text { 5.Facebookta geçirdiğim zaman radyo dinlediğim } \\
\text { zamandan daha fazla }\end{array}$ & $10,4 \%$ & $5,6 \%$ & $8,8 \%$ & $20,0 \%$ & $55,2 \%$ \\
\hline $\begin{array}{l}\text { 6.Facebook'ta geçirdiğim zaman televizyon izlerken } \\
\text { geçirdiğim zamandan daha fazla }\end{array}$ & $12,0 \%$ & $12,0 \%$ & $22,4 \%$ & $24,8 \%$ & $28,8 \%$ \\
\hline $\begin{array}{l}\text { 7.Cep telefonumdan mutlaka Facebook sayfamı } \\
\text { açıyorum }\end{array}$ & $4,0 \%$ & $4,8 \%$ & $3,2 \%$ & $20,0 \%$ & $68,0 \%$ \\
\hline $\begin{array}{l}\text { 8.Gündemdeki haberleri gazeteden takip etmek yerine } \\
\text { Facebook'taki paylaşımlardan öğrenmeyi tercih } \\
\text { ediyorum }\end{array}$ & $7,2 \%$ & $9,6 \%$ & $22,4 \%$ & $29,6 \%$ & $31,2 \%$ \\
\hline $\begin{array}{l}\text { 9. Arkadaşlarımın ilgisini çeken bir haber veya video } \\
\text { ilgimi çekerse bende o haberi arkadaşlarımla paylaşırım }\end{array}$ & $3,3 \%$ & $5,7 \%$ & $8,2 \%$ & $32,0 \%$ & $50,8 \%$ \\
\hline $\begin{array}{l}\text { 10.Dinlemekten zevk aldığım, sevdiğim bir şarkıyı } \\
\text { mutlaka Facebook'ta paylaşırım }\end{array}$ & $2,4 \%$ & $9,8 \%$ & $10,6 \%$ & $28,5 \%$ & $48,8 \%$ \\
\hline $\begin{array}{l}\text { 11.Facebook'ta bulunan sanatçı hayran sayfalarını sik } \\
\text { s1k ziyaret ediyorum }\end{array}$ & $8,9 \%$ & $21,8 \%$ & $16,9 \%$ & $29,8 \%$ & $22,6 \%$ \\
\hline $\begin{array}{l}\text { 12.Sevdiğim radyo ve tv kanallarının Facebook } \\
\text { sayfalarını mutlaka ziyaret ediyorum }\end{array}$ & $7,8 \%$ & $17,2 \%$ & $25,0 \%$ & $35,3 \%$ & $14,7 \%$ \\
\hline $\begin{array}{l}\text { 13.Radyodan müzik dinlemek yerine Facebook aracilığ } \\
\text { ile müzik dinlemeyi tercih ediyorum }\end{array}$ & $10,3 \%$ & $16,4 \%$ & $24,1 \%$ & $17,2 \%$ & $31,9 \%$ \\
\hline $\begin{array}{l}\text { 14.Facebook üzerinde yer alan oyunları oynayarak } \\
\text { zaman geçirmek hoşuma gidiyor }\end{array}$ & $22,4 \%$ & $20,7 \%$ & $10,3 \%$ & $25,9 \%$ & $20,7 \%$ \\
\hline
\end{tabular}


(Tablo 17 devamı)

\begin{tabular}{|l|l|l|l|l|l|}
\hline $\begin{array}{l}\text { 15. Arkadaşlarımın önerdiği konser ve etkinlik haber ve } \\
\text { önerilerini dikkate alıyor ve bu önerilere uyarak farklı } \\
\text { etkinliklere katılıyorum }\end{array}$ & $7,0 \%$ & $17,4 \%$ & $19,1 \%$ & $36,5 \%$ & $20,0 \%$ \\
\hline $\begin{array}{l}\text { 16.Facebook benim için en önemli haber alma } \\
\text { araçlarından biri }\end{array}$ & $3,4 \%$ & $9,5 \%$ & $18,1 \%$ & $46,6 \%$ & $22,4 \%$ \\
\hline $\begin{array}{l}\text { 17.Hakkımda ki bir bilgiyi / gelişmeyi arkadaşlarıma } \\
\text { telefon ile söylemek yerine Facebook aracılığı ile } \\
\text { söylemeyi tercih ederim }\end{array}$ & $7,8 \%$ & $18,1 \%$ & $14,7 \%$ & $34,5 \%$ & $25,0 \%$ \\
\hline $\begin{array}{l}\text { 18.Hakkımda ki bir bilgiyi / gelişmeyi arkadaşlarıma } \\
\text { yüz yüze görüşmek yerine söylemek yerine Facebook } \\
\text { aracılığı ile söylemeyi tercih ederim }\end{array}$ & $15,5 \%$ & $17,2 \%$ & $22,4 \%$ & $25,0 \%$ & $19,8 \%$ \\
\hline $\begin{array}{l}\text { 19.Facebook'ta farklı bir dünya buluyorum } \\
\text { 20.Arkadaşlarımla telefonla konuşmak yerine Facebook } \\
\text { aracılığı ile chat yaparak iletişim kurmak beni daha } \\
\text { fazla mutlu ediyor }\end{array}$ & $11,2 \%$ & $19,8 \%$ & $19,8 \%$ & $25,9 \%$ & $23,3 \%$ \\
\hline $\begin{array}{l}\text { 21.Facebook'a girmediğim zamanlar hayatımda bir } \\
\text { şeylerin eksik olduğunu hissediyorum }\end{array}$ & $17,2 \%$ & $17,2 \%$ & $14,7 \%$ & $31,0 \%$ & $19,8 \%$ \\
\hline 22.Facebook'suz bir hayat düşünemiyorum & $20,7 \%$ & $15,5 \%$ & $18,1 \%$ & $31,0 \%$ & $14,7 \%$ \\
\hline
\end{tabular}

\subsection{Analizler}

\subsubsection{Y Kuşağının Facebook’u Kullanımına Yönelik Testler}

Y kuşağının Facebook sosyal ağını faal olarak kullanımlarını ölçmek amacıyla anketin $4,9,10,11,12,13,14,15,16$. soruları tek örneklem t testi ile test edilmiş ve sonuçları Tablo 18 'de gösterilmiştir. 
Tablo 18: Y Kuşağının Facebook kullanımına Yönelik Analizler

\begin{tabular}{|c|c|c|c|c|}
\hline & Ortalama & $\begin{array}{l}\text { Std. } \\
\text { sapma }\end{array}$ & $\mathrm{t}$ & $\mathrm{p}$ \\
\hline $\begin{array}{l}\text { 4.Facebook'ta arkadaşımın satın alarak } \\
\text { fotoğrafını paylaştığı bir ürün ilgimi } \\
\text { çekerse o ürünü bende satın alırım }\end{array}$ & 2,56 & 1,29 & $-7,329$ & $0,000 *$ \\
\hline $\begin{array}{l}\text { 9.Arkadaşlarımın ilgisini çeken bir haber } \\
\text { veya video ilgimi çekerse bende o haberi } \\
\text { arkadaşlarımla paylaşırım }\end{array}$ & 4,21 & 1,04 & 8,649 & $0,000^{*}$ \\
\hline $\begin{array}{l}\text { 10.Dinlemekten zevk aldığım, sevdiğim } \\
\text { bir şarkıyı mutlaka Facebook'ta } \\
\text { paylaşırım }\end{array}$ & 4,11 & 1,10 & 7,227 & $0,000 *$ \\
\hline $\begin{array}{l}\text { 11.Facebook'ta bulunan sanatçı hayran } \\
\text { sayfalarını sik sik ziyaret ediyorum }\end{array}$ & 3,35 & 1,29 & $-0,390$ & 0,697 \\
\hline $\begin{array}{l}\text { 12.Sevdiğim radyo ve tv kanallarının } \\
\text { Facebook sayfalarını mutlaka ziyaret } \\
\text { ediyorum }\end{array}$ & 3,32 & 1,15 & $-0,756$ & 0,451 \\
\hline $\begin{array}{l}\text { 13.Radyodan müzik dinlemek yerine } \\
\text { Facebook aracılığı ile müzik dinlemeyi } \\
\text { tercih ediyorum }\end{array}$ & 3,44 & 1,36 & 0,314 & 0,754 \\
\hline $\begin{array}{l}\text { 14.Facebook üzerinde yer alan oyunları } \\
\text { oynayarak zaman geçirmek hoşuma } \\
\text { gidiyor }\end{array}$ & 3,02 & 1,49 & $-2,774$ & $0,006^{*}$ \\
\hline $\begin{array}{l}\text { 15. Arkadaşlarımın önerdiği konser ve } \\
\text { etkinlik haber ve önerilerini dikkate } \\
\text { alıyor ve bu önerilere uyarak farklı } \\
\text { etkinliklere katıliyorum }\end{array}$ & 3,45 & 1,19 & 0,469 & 0,640 \\
\hline $\begin{array}{l}\text { 16. Facebook benim için en önemli haber } \\
\text { alma araçlarından biri }\end{array}$ & 3,75 & 1,02 & 3,694 & $0,000 *$ \\
\hline
\end{tabular}
$* \mathrm{p}<0.05$

Uygulanan anketin 4, 9, 10, 14 ve 16. Numaraları ifadelerine Y kuşağının katılma düzeyleri anlamlı bulunmuştur $(\mathrm{p}<0.05)$.

\subsubsection{Y Kuşağında Cinsiyete Göre Facebook Kullanımının Geleneksel Mecralarla Kıyası}

Gençlerin cinsiyetlerine göre sosyal medyayı geleneksel medyadan daha fazla kullanmaya ilişkin görüşleri arasında fark olup olmadığı bağımsız örneklemler için t testi ile test edilmiş ve sonuçları Tablo 19'da gösterilmiştir. 
Tablo 19: Y Kuşağının Cinsiyete Göre Facebook’ta Zaman Geçirme Analizi

\begin{tabular}{|l|l|c|l|l|l|}
\hline & Cinsiyet & Ortalama & $\begin{array}{l}\text { Std. } \\
\text { sapma }\end{array}$ & T & p \\
\hline $\begin{array}{l}\text { 5.Facebookta geçirdiğim zaman radyo } \\
\text { dinlediğim zamandan daha fazla }\end{array}$ & Erkek & 4,05 & 1,36 & $-0,206$ & 0,837 \\
\cline { 2 - 7 } Kadın & 4,10 & 1,29 & & \\
\hline $\begin{array}{l}\text { 6.Facebook’ta geçirdiğim zaman } \\
\text { televizyon izlerken geçirdiğim zamandan } \\
\text { daha fazla }\end{array}$ & Erkek & 3,39 & 1,37 & $-0,835$ & 0,405 \\
\cline { 2 - 7 } & Kadın & 3,61 & 1,28 & & \\
\hline $\begin{array}{l}\text { 7.Cep telefonumdan mutlaka Facebook } \\
\text { sayfamı açıyorum }\end{array}$ & Erkek & 4,47 & 1,03 & 0,114 & 0,909 \\
\cline { 2 - 7 } $\begin{array}{l}\text { 8.Gündemdeki haberleri gazeteden takip } \\
\text { etmek yerine Facebook’taki } \\
\text { paylaşımlardan öğrenmeyi tercih } \\
\text { ediyorum }\end{array}$ & Krkek & 4,45 & 0,95 & & \\
\cline { 2 - 7 } & Kadın & 4,03 & 1,03 & & \\
\hline
\end{tabular}

$* \mathrm{p}<0.05$

Sonuçlara göre kadın ve erkeklere göre "gündemdeki haberleri gazeteden takip etmek yerine Facebook'taki paylaşımlardan öğrenmeyi tercih etme" eğilimleri arasında anlamlı bir fark bulunmuştur $(\mathrm{p}<0.05)$.

\subsubsection{Y Kuşağının Cinsiyete Göre Facebook Kullanma Düzeyleri}

Y kuşağının cinsiyetlerine göre Facebook'u faal olarak kullanma düzeylerine ilişkin görüşleri arasında fark olup olmadığı bağımsız örneklemler için t testi ile test edilmiş ve sonuçları Tablo 20'de gösterilmiştir.

Tablo 20: Y Kuşağının Cinsiyete Göre Facebook Kullanımı Analizi

\begin{tabular}{|c|c|c|c|c|c|}
\hline & Cinsiyet & Ortalama & $\begin{array}{l}\text { Std. } \\
\text { sapma }\end{array}$ & $\mathrm{T}$ & $\mathrm{p}$ \\
\hline \multirow{2}{*}{$\begin{array}{l}\text { 4.Facebook'ta arkadaşımın satın } \\
\text { fotoğgrafını paylaştığı bir } \\
\text { çekerse o ürün } \\
\text { çünü bende satın alırım }\end{array}$} & Erkek & 2,60 & 1,34 & 0,253 & 0,801 \\
\hline & Kadın & 2,54 & 1,21 & & \\
\hline \multirow{2}{*}{$\begin{array}{l}\text { 9.Arkadaşlarımın ilgisini çeken bir haber } \\
\text { veya video ilgimi çekerse bende o haberi } \\
\text { arkadaşlarımla paylaşırım }\end{array}$} & Erkek & 4,15 & 1,09 & $-1,425$ & 0,157 \\
\hline & Kadın & 4,43 & 0,80 & & \\
\hline \multirow{2}{*}{$\begin{array}{l}\text { 10.Dinlemekten zevk aldığım, sevdiğim } \\
\text { bir şarkıyı mutlaka Facebook'ta } \\
\text { paylaşırım }\end{array}$} & \begin{tabular}{|l} 
Erkek \\
\end{tabular} & 3,99 & 1,15 & $-1,884$ & 0,062 \\
\hline & Kadın & 4,38 & 0,91 & & \\
\hline \multirow{2}{*}{$\begin{array}{l}\text { 11.Facebook'ta bulunan sanatçı hayran } \\
\text { sayfalarını s1k s1k ziyaret ediyorum }\end{array}$} & Erkek & 3,30 & 1,30 & $-0,561$ & 0,576 \\
\hline & Kadın & 3,44 & 1,23 & & \\
\hline \multirow{2}{*}{$\begin{array}{l}\text { 12.Sevdiğim radyo ve tv kanallarının } \\
\text { Facebook sayfalarını mutlaka ziyaret } \\
\text { ediyorum }\end{array}$} & Erkek & 3,19 & 1,18 & $-1,869$ & 0,064 \\
\hline & Kadın & 3,61 & 1,00 & & \\
\hline \multirow{2}{*}{$\begin{array}{l}\text { 13.Radyodan müzik dinlemek yerine } \\
\text { Facebook arac1lı̆̆1 ile müzik dinlemeyi } \\
\text { tercih ediyorum }\end{array}$} & Erke & 3,32 & 1,34 & $-1,461$ & 0,147 \\
\hline & Kadın & 3,71 & 1,35 & & \\
\hline \multirow{2}{*}{$\begin{array}{l}\text { 14.Facebook üzerinde yer alan oyunları } \\
\text { oynayarak zaman geçirmek hoşuma } \\
\text { gidiyor }\end{array}$} & Erkek & 2,77 & 1,46 & $-2,704$ & $0,008 *$ \\
\hline & Kadın & 3,55 & 1,43 & & \\
\hline
\end{tabular}


(Tablo 20 devamı)

\begin{tabular}{|l|l|c|c|c|c|}
\hline $\begin{array}{l}\text { 15. Arkadaşlarımın önerdiği konser ve } \\
\text { etkinlik haber ve önerilerini dikkate alıyor }\end{array}$ & Erkek & 3,47 & 1,22 & $-0,197$ & 0,844 \\
\hline $\begin{array}{l}\text { ve bu önerilere uyarak farklı etkinliklere } \\
\text { katılıyorum }\end{array}$ & Kadın & 3,51 & 1,10 & & \\
\hline $\begin{array}{l}\text { 16.Facebook benim için en önemli haber } \\
\text { alma araçlarından biri }\end{array}$ & Erkek & 3,63 & 1,08 & $-1,747$ & 0,083 \\
\cline { 2 - 7 } & Kadın & 3,97 & 0,82 & & \\
\hline
\end{tabular}

$* \mathrm{p}<0.05$

Y Kuşağına ait kadın ve erkeklerin "Facebook üzerinde yer alan oyunları oynayarak zaman geçirmek hoşuma gidiyor" ifadesine katılım düzeyleri arasında anlamlı bir fark bulunmuştur ( $p>0.05)$. Y kuşağı bireylerinin cinsiyetlerine göre anketin 4,9, $10,11,12,13$, 15 ve 16. ifadelerine ilişkin görüşleri farkl1laşmamaktadır( $\mathrm{p}>0.05)$.

\subsubsection{Y Kuşağının Cinsiyete Göre Facebook'un Bağımlılığa Yol Açtığına İlişkin}

\section{Görüş Analizi}

Araştırmaya katılan Y kuşağı bireylerinin cinsiyetlerine göre Facebook’un bağımlığa yol açtığına ilişkin görüşleri arasında fark olup olmadığı bağımsız örneklemler için t testi ile test edilmiş ve sonuçları Tablo 21 'de gösterilmiştir.

Tablo 21: Facebook Bağımlığının Cinsiyete Göre Analizi

\begin{tabular}{|c|c|c|c|c|c|}
\hline & Cinsiyet & Ort. & $\begin{array}{c}\text { Std. } \\
\text { sapma }\end{array}$ & $\mathrm{t}$ & $\mathrm{p}$ \\
\hline \multirow{2}{*}{$\begin{array}{l}\text { 17.Hakkımda ki bir bilgiyi / gelişmeyi arkadaşlarıma } \\
\text { telefon ile söylemek yerine Facebook aracılığı ile } \\
\text { söylemeyi tercih ederim }\end{array}$} & Erkek & 3,53 & 1,22 & $-0,183$ & 0,855 \\
\hline & Kadın & 3,58 & 1,31 & & \\
\hline \multirow{2}{*}{$\begin{array}{l}\text { 18.Hakkımda ki bir bilgiyi / gelişmeyi arkadaşlarıma } \\
\text { yüz yüze görüşmek yerine söylemek yerine Facebook } \\
\text { aracıllı̆̆ ile söylemeyi tercih ederim }\end{array}$} & Erkek & 2,99 & 1,26 & $-2,159$ & $0,033^{*}$ \\
\hline & Kadın & 3,55 & 1,43 & & \\
\hline \multirow{2}{*}{ 19.Facebook'ta farklı bir dünya buluyorum } & Erkek & 3,67 & 1,19 & 0,255 & 0,799 \\
\hline & Kadın & 3,61 & 1,24 & & \\
\hline \multirow{2}{*}{$\begin{array}{l}\text { 20.Arkadaşlarımla telefonla konuşmak yerine } \\
\text { Facebook aracılığı ile chat yaparak iletişim kurmak } \\
\text { beni daha fazla mutlu ediyor }\end{array}$} & Erkek & 3,15 & 1,30 & $-1,749$ & 0,083 \\
\hline & Kadın & 3,61 & 1,35 & & \\
\hline \multirow{2}{*}{$\begin{array}{l}\text { 21.Facebook'a girmediğim zamanlar hayatımda bir } \\
\text { şeylerin eksik olduğunu hissediyorum }\end{array}$} & Erkek & 3,00 & 1,44 & $-2,128$ & $0,036 *$ \\
\hline & Kadın & 3,58 & 1,20 & & \\
\hline \multirow{2}{*}{ 22.Facebook’suz bir hayat düşünemiyorum } & Erkek & 2,89 & 1,38 & $-1,648$ & 0,102 \\
\hline & Kadın & 3,34 & 1,34 & & \\
\hline
\end{tabular}

${ }^{*} \mathrm{p}<0.05$

Kadın ve erkeklerin "Hakkımda ki bir bilgiyi / gelişmeyi arkadaşlarıma yüz yüze görüşmek yerine söylemek yerine Facebook aracılığı ile söylemeyi tercih ederim" ve "Facebook'a girmediğim zamanlar hayatımda bir şeylerin eksik olduğunu hissediyorum" 
ifadelerine katılım düzeyleri arasında anlamlı bir fark bulunmuştur. Katılımcıların cinsiyetlerine göre anketin 17, 19, 20 ve 22. ifadelerine ilişkin görüşleri farklılaşmamaktadır $(\mathrm{p}>0.05)$.

\subsubsection{Y Kuşağının Facebook Kullanma Düzeyinin Yaşa Göre Analizi.}

Yaşa göre Facebook'u faal olarak kullanma düzeylerine ilişkin görüşleri arasında fark olup olmadığı bağımsız örneklemler için t testi ile test edilmiş ve sonuçları Tablo 22 'de gösterilmiştir.

Tablo 22: Yaşa Göre Facebook Kullanma Analizi

\begin{tabular}{|c|c|c|c|c|c|}
\hline & Yaş & Ort. & $\begin{array}{c}\text { Std. } \\
\text { sapma }\end{array}$ & $\mathrm{T}$ & $\mathrm{p}$ \\
\hline \multirow{2}{*}{$\begin{array}{l}\text { 4.Facebook'ta arkadaşımın satın alarak fotoğrafını } \\
\text { paylaştı̆̆ bir ürün ilgimi çekerse o ürünü bende satın } \\
\text { alırım }\end{array}$} & $17-23$ & 2,53 & 1,36 & $-0,380$ & 0,704 \\
\hline & $24-33$ & 2,63 & 1,21 & & \\
\hline \multirow{2}{*}{$\begin{array}{l}\text { 9.Arkadaşlarımın ilgisini çeken bir haber veya video } \\
\text { ilgimi çekerse bende o haberi arkadaşlarımla paylaşırım }\end{array}$} & 17-23 & 4,07 & 1,10 & $-1,829$ & 0,070 \\
\hline & 24-33 & 4,43 & 0,93 & & \\
\hline \multirow{2}{*}{$\begin{array}{l}\begin{array}{l}\text { 10.Dinlemekten zevk aldığım, sevdiğim bir şarkıyı } \\
\text { mutlaka Facebook'ta paylaşırım }\end{array} \\
\end{array}$} & \begin{tabular}{|l|}
$17-23$ \\
\end{tabular} & 3,99 & 1,18 & $-1,413$ & 0,160 \\
\hline & \begin{tabular}{|l|}
$24-33$ \\
\end{tabular} & 4,28 & 0,95 & & \\
\hline \multirow{2}{*}{$\begin{array}{l}\text { 11.Facebook'ta bulunan sanatçı hayran sayfalarını sık sık } \\
\text { ziyaret ediyorum }\end{array}$} & \begin{tabular}{|l|}
$17-23$ \\
\end{tabular} & 3,19 & 1,34 & $-1,435$ & 0,154 \\
\hline & $24-33$ & 3,53 & 1,18 & & \\
\hline \multirow{2}{*}{$\begin{array}{l}\text { 12.Sevdiğim radyo ve tv kanallarının Facebook } \\
\text { sayfalarını mutlaka ziyaret ediyorum }\end{array}$} & $17-23$ & 3,20 & 1,25 & $-1,311$ & 0,193 \\
\hline & 24-33 & 3,49 & 0,96 & & \\
\hline \multirow{2}{*}{$\begin{array}{l}\text { 13.Radyodan müzik dinlemek yerine Facebook aracılığ } 1 \\
\text { ile müzik dinlemeyi tercih ediyorum }\end{array}$} & $17-23$ & 3,27 & 1,38 & $-1,645$ & 0,103 \\
\hline & \begin{tabular}{|l|}
$24-33$ \\
\end{tabular} & 3,70 & 1,30 & & \\
\hline \multirow{2}{*}{$\begin{array}{l}\text { 14.Facebook üzerinde yer alan oyunları oynayarak zaman } \\
\text { geçirmek hoşuma gidiyor }\end{array}$} & \begin{tabular}{|l|}
$17-23$ \\
\end{tabular} & 2,83 & 1,50 & $-1,824$ & 0,071 \\
\hline & \begin{tabular}{|l|}
$24-33$ \\
\end{tabular} & 3,35 & 1,41 & & \\
\hline \multirow{2}{*}{$\begin{array}{l}\text { 15. Arkadaşlarımın önerdiği konser ve etkinlik haber ve } \\
\text { önerilerini dikkate alıyor ve bu önerilere uyarak farklı } \\
\text { etkinliklere katıllyorum }\end{array}$} & \begin{tabular}{|l}
$17-23$ \\
\end{tabular} & 3,26 & 1,19 & $-2,490$ & 0,014* \\
\hline & 24-33 & 3,81 & 1,10 & & \\
\hline \multirow{2}{*}{$\begin{array}{l}\text { 16.Facebook benim için en önemli haber alma } \\
\text { araçlarından biri }\end{array}$} & \begin{tabular}{|l|}
$17-23$ \\
\end{tabular} & 3,63 & 1,00 & $-1,277$ & 0,204 \\
\hline & 24-33 & 3,88 & 1,03 & & \\
\hline
\end{tabular}

$* \mathrm{p}<0.05$

Yaşı 17-23 ve yaşı 24-33 arasında olan gençlerin “Arkadaşlarımın önerdiği konser ve etkinlik haber ve önerilerini dikkate alıyor ve bu önerilere uyarak farklı etkinliklere katılıyorum" ifadesine katılım düzeyleri arasında anlamlı bir fark bulunmuştur(p<0.05). Ancak gençlerin yaşlarına göre anketin 4, 9, $10,11,12,13,14$ ve 16. ifadelerine ilişkin görüşleri farklılaşmamaktadır(p>0.05). Y kuşağı bireyleri Facebook’ta homojen özellikler sergilerken, sosyalleşme ve dışarıya çıkma konusunda genç kuşak bireyleri daha aktif bir katılım göstermektedir. Y kuşağının son bölümünde doğan ve daha genç olan bireyler sosyal 
medyayı sosyal hayatlarını belirleyen bir unsur olarak kullanmakta ve sosyal medyanın dışında kalan reel sosyal hayatlarında Facebook'u referans almaktadır.

\subsubsection{Y Kuşağının Yaşa Göre Facebook’un Bağımlılığa Yol Açtığına İlişkin Görüş Analizi}

Yaşa göre Facebook'un bağımlığa yol açtığına ilişkin görüşleri arasında fark olup olmadığı bağımsız örneklemler için $\mathrm{t}$ testi ile test edilmiş ve sonuçları Tablo 23'de gösterilmiştir.

Tablo 23: Yaşa Göre Facebook Bağımlılığı Analizi

\begin{tabular}{|c|c|c|c|c|c|}
\hline & Yaş & Ort. & $\begin{array}{c}\text { Std. } \\
\text { sapma }\end{array}$ & $\mathrm{t}$ & $\mathrm{p}$ \\
\hline \multirow{2}{*}{$\begin{array}{l}\text { 17.Hakkımda ki bir bilgiyi / gelişmeyi } \\
\text { arkadaşlarıma telefon ile söylemek yerine } \\
\text { Facebook aracılığı ile söylemeyi tercih ederim }\end{array}$} & $17-23$ & 3,31 & 1,28 & $-2,399$ & $0,018 *$ \\
\hline & 24-33 & 3,88 & 1,16 & & \\
\hline \multirow{2}{*}{$\begin{array}{l}\text { 18.Hakkımda ki bir bilgiyi / gelişmeyi } \\
\text { arkadaşlarıma yüz yüze görüşmek yerine } \\
\text { söylemek yerine Facebook aracılığ ile } \\
\text { söylemeyi tercih ederim }\end{array}$} & $17-23$ & 3,00 & 1,40 & $-1,619$ & 0,108 \\
\hline & $24-33$ & 3,42 & 1,22 & & \\
\hline \multirow{2}{*}{ 19.Facebook’ta farklı bir dünya buluyorum } & $17-23$ & 3,54 & 1,24 & $-1,405$ & 0,163 \\
\hline & 24-33 & 3,86 & 1,13 & & \\
\hline \multirow{2}{*}{$\begin{array}{l}\text { 20.Arkadaşlarımla telefonla konuşmak yerine } \\
\text { Facebook aracılığı ile chat yaparak iletişim } \\
\text { kurmak beni daha fazla mutlu ediyor }\end{array}$} & 17-23 & 3,06 & 1,33 & $-2,461$ & $0,015^{*}$ \\
\hline & 24-33 & 3,67 & 1,25 & & \\
\hline \multirow{2}{*}{$\begin{array}{l}\text { 21.Facebook'a girmediğim zamanlar hayatımda } \\
\text { bir şeylerin eksik olduğunu hissediyorum }\end{array}$} & $17-23$ & 2,99 & 1,42 & $-1,882$ & 0,062 \\
\hline & $24-33$ & 3,49 & 1,32 & & \\
\hline \multirow{2}{*}{ 22.Facebook’suz bir hayat düşünemiyorum } & $17-23$ & 2,79 & 1,43 & $-2,402$ & $0,018^{*}$ \\
\hline & 24-33 & 3,42 & 1,22 & & \\
\hline
\end{tabular}

$* \mathrm{p}<0.05$

Y kuşağı bireylerinin yaşlarına göre "Hakkımda ki bir bilgiyi / gelişmeyi arkadaşlarıma telefon ile söylemek yerine Facebook aracılığı ile söylemeyi tercih ederim”, "Arkadaşlarımla telefonla konuşmak yerine Facebook aracılı̆̆ı ile chat yaparak iletişim kurmak beni daha fazla mutlu ediyor" ve "Facebook'suz bir hayat düşünemiyorum" ifadelerine katılım düzeyleri arasında anlamlı bir fark bulunmuştur $(\mathrm{p}<0.05)$. Katılımcıların yaşa göre anketin 18, 19, ve 21. ifadelerine ilişkin görüşleri farkl1laşmamaktadır(p>0.05).

\section{SONUÇ}

Geçtiğimiz yüzyılda yaşanan teknolojik gelişmeler dünya tarihinde köklü değişikliklere neden olmuştur. Teknoloji özellikle 21 yüzyılda toplumsal gelişmenin başrol 
oyuncusu olmuştur. Yeni iletişim teknolojileri sonucunda ortaya çıkan sosyal medya sadece medyanın değil bireylerim yaşam tarzlarının da yeniden şekillenmesine neden olmuştur. $\mathrm{Bu}$ durumdan en fazla etkilenen kuşak ise 1979 ile 1999 yılında doğan ve Y kuşağı olarak adlandırılan kuşak olmuştur. Önceki kuşakların teknoloji ile ilişkileri limitli iken Y kuşağı özellikle internet teknolojileri ve sosyal medya ile daha fazla ilgilenmiştir.

Yapılan araştırmalar Y kuşağı olarak adlandırılan kuşağın önceki kuşaklara göre daha pratik, dinamik ve daha sonuç odaklı bir kuşak olduğunu göstermiştir. Bu kuşağın üyeleri önceki kuşaklardan daha sabırsız, daha hırslı ve sadakat duygusu daha zayıf bir kuşak olarak adlandırılmıştır. Y kuşağının bir diğer önemli özelliği de internet ve çok kanallı televizyonlar ile büyümüş olmalarıdır.

Y kuşağının dünyanın en popüler sosyal medya ağı Facebook'u kullanma alışkanlıkları üzerine yapılan bu araştırmada teknoloji ile içiçe bir hayat sürdüren Y kuşağının \% 28,2'sinin günde üç saat Facebook hesaplarını açık tuttuğu tespit edilmiştir. Dört yıldan uzun süredir Facebook hesabı olanların oranı \% 58,7'dir. Türkiye'de Facebook'un özellikle son beş yılda büyüme göstermesi ve Türkiye’nin dönem içinde dünyanın en çok Facebook kullanan dördüncü ülkesi konumuna kadar çıkmasında bu kuşağın sosyal ağa gösterdiği talebin bir sonucu olarak yorumlanabilir.

Araştırma bulgularına göre Facebook Y kuşağının müzik dinleme ve geleneksel medyayı tüketim alışkanlıkları üzerinde etkisi bulunmaktadır. Y kuşağı dinlediği müziği Facebook aracılığı dinlemekte ve yine aynı mecra ile diğer arkadaşları ile paylaşmakta, sevdiği müzik yorumcuları ile Facebook üzerinden iletişim kurmayı radyoya göre daha fazla tercih etmektedir. Radyodan müzik dinlemek yerine Facebook aracılığı ile yapılan paylaşımlardan müzik dinlemeyi tercih eden kuşak sadece müzik paylaşımı değil içeriğinde herhangi bir haber ve benzeri bir gündem konusu içeren görsel fotoğraf ve video paylaşımı da yapmaktadir.

Y kuşağı Facebook aracılığı ile paylaşımda bulunmakta ve sosyal medyanın en önemli özelliği olan interaktifliğe önem vermektedir. Yapılan araştırmada Y kuşağının Facebook’ta geçirdiği zamanın radyo dinlemek için geçirdiği zamandan daha fazla olduğu tespit edilmiştir. Aynı durum televizyon için geçerli değildir. Y kuşağı Facebook’u radyo mecrasından daha fazla kullanırken televizyon mecrasını henüz tam anlamıyla terk etmemiş ve televizyon mecrasını Facebook’tan daha fazla kullandığını belirtmiştir. Katılımcılar cep telefonlarından 
her gün Facebook'taki hesaplarına girdiklerini belirtmiş ayrıca Facebook'u önemli bir haber alma aracı olarak algıladıklarını açıklamıştır.

Kuşağa ait bireylerinin tüketim alışkanlıkları üzerinde yapılan analizde artan yönde bir eğilimle Facebook'u referans alarak tüketim yapmaya başladıkları ortaya çıkmıştır. Ürün tüketimi yaparken deneyime önem veren Y kuşağı Facebook aracılı̆̆ı ile ürün hakkında bilgilenmeyi ama son alımı yaparken ürünü görmeyi veya farklı bir deneyim ile ürün hakkında bilgilenmeyi tercih etmektedir.

Araştırmada Y kuşağının Facebook'u kullanım düzeyleri ile ilgili yaşa ve cinsiyete göre bir farklılık olup olmadığı da incelenmiştir. Bu incelemede Y kuşağı 1996 yılı sonrası ve öncesi doğanlar olmak üzere iki farklı yaş grubuna ayrılmıştır. Bu tarihsel gruplandırmanın 1996 yılına göre yapılmasında Türk internet tarihinde yaşanan ilkler referans gösterilerek yapılmıştır. Buna göre 1979 ile 1996 yılları arasında yaşayan ve yaşı bugün 33 olan Y kuşağı temsilcileri çocukluklarını internetsiz geçirirken, 1996 yılından sonra doğan kuşak üyeleri çocukluk yıllarını da internet ve çok kanallı televizyonlarla geçirmişlerdir. İnternet Türkiye’ye 1994 yılında gelmiş ama internetin Türkiye'de yaygınlaşması 1996 yılında yapılan çalışmalarla hızlanmıştır. 1996 yılında Ulakbim kurulmuş, Turnet hizmete girmiştir, yine 1996 yılında Türkiye'deki internet hızı 512 Kbps’ye çıkartılarak yaygınlaşması için önemli bir adım atılmıştır. Öğrenci seçme ve yerleştirme merkezi 1996 yılında ilk kez ÖSS, ÖYS ve TUS sınav sonuçlarını internet yolu ile açıklamıştır. Bu tarihsel dönüm noktalarından hareket ederek 1996 yılından sonra doğan Y kuşağı üyelerine yapılan araştırmada Y kuşağının Facebook kullanım alışkanlıklarının yaşa göre değişim gösterdiği tespit edilmiştir. İnternet ile gençliğini yaşayan 24 yaş ve üstü grubu Y kuşağı üyeleri ile 24 yaş ve altı kuşak üyelerinin başta Facebook olmak üzere tüm sosyal medya kullanımlarında farklılıklar tespit edilmiştir.

Y kuşağının Facebook'ta radyodan daha fazla zaman geçirmesi, sosyal ağa cep telefonundan bağlanması ve mecrayı bir haber alma aracı gibi görmesinde cinsiyete göre bir farklılık göstermemektedir. Araştırmada kuşak bireylerinin Facebook'u genel kullanma alışkanlıklarında cinsiyete göre homojen özellikler taşıdığı görülmüştür. Cinsiyete göre en yüksek farklılık gösteren konu Facebook aracılığı ile oynanan çevrim içi oyunlarda ortaya çıkmıştır. Erkekler bu oyunlara bayanlara göre daha fazla ilgi duyduğunu belirtmiştir. Cinsiyete göre farklılık gösteren bir diğer eylem ise Facebook aracılığı ile yapılan bilgi paylaşımlarında görülmüştür. Bayanlar erkeklere göre Facebook’u daha çok bilgi ve deneyim paylaşımı amacıyla kullanmaktadır. 
Araştırma sonucunda 1996 yılından sonra doğan kuşak üyelerinin sosyal yaşamlarını daha çok sosyal medya ağı Facebook aracılığı ile yönlendirdiği ortaya çıkmıştır. 1996 yılından sonra doğan ve çocukluk yıllarını da internet ile geçiren kuşak üyeleri, 1996 yılından önce doğan ve internetle çocukluk ve gençlik yıllarında tanışan üyelere göre Facebook'u sosyal hayatlarının bir parçası olarak konumlandırmaktadır. 1996 yılından doğan Y kuşağı, etkinlikleri Facebook aracılığı ile takip etmekte ve katılım durumlarını yine Facebook aracılığı ile gelen öneriler sonucunda netleştirmektedir.

1996 yılında sonra doğan Y kuşağı iletişimini daha çok Facebook aracılığı ile gerçekleştirmektedir. Kendileri hakkındaki bilgileri geleneksel iletişim yöntemleri yerine Facebook aracılığı ile arkadaşlarıyla paylaşmayı tercih eden yaş grubu Facebook aracılığı ile iletişim kurmayı "yüz yüze" konuşmaya , "telefon” ile konuşmaya tercih etmektedir. Bu durum 1996 yılından önce doğanlar için geçerli değildir.

Facebook bağımlılığı ile ilgili yapılan analizlerde Y kuşağının "Facebook'un bağımlılık yarattığı” konusuna yüzde 100 oranında katılmadığı sonucunu ortaya çıkartmıştır. Y kuşağı Facebook'un bağımlılık yarattı̆ğna katılmamaktadırlar. Bu durum 1996 yılından önce ve sonra doğan bireyler içinde benzer sonuçlar vermektedir.

Y kuşağının özellikle son döneminde doğan bireylerinin ilk dönemde doğanlara göre farklı görüşler vermesi kuşakların da kendi içlerinde gruplandırılması gerektiği konusunu tartışmaya açmaktadır. 1979 ile 1999 yıllarını kapsayan yirmi yıllık dönemde özellikle internet mecrasının yaygınlaşması ve sonrasında sosyal medya ağlarının popüler olması Türkiye'deki Y kuşağını iki farklı alt kategori de gruplandırma ihtiyacını ortaya çıkartmıştır. $\mathrm{Bu}$ gruplandirmada sadece geleneksel medya ile yetişen ile geleneksel ve yeni medya ile yetişen bireylerin ayrı ayrı değerlendirilmesi gerekmektedir. Y kuşağının son dönemlerinde doğanlar bir sonraki kuşak olan Z kuşağının hayat seyirleri ile de ilgili önemli ipuçları vermektedir. Bu ipuçlarında en önemli faktör ise teknoloji ve internet mecrasında yaşanan gelişmelerdir. $\mathrm{Bu}$ nedenledir ki Y kuşağını anlamak ve 2020'li yılların dünyasını elinde tutacak olan bu kuşağı tanımlamak için onların yeni medya ve sosyal medya ile olan ilişkilerinin net bir biçimde saptanması ve yeni medyanın yarattığı bu yeni kuşağın biçimlendirmeye başladığı yeni dünya düzeninin hangi yönde ilerleyeceğinin tartışılması gerekmektedir. 


\section{Kaynakça}

Akar,E. (2010). Sosyal Medya Pazarlamasi: Sosyal Webde Pazarlama Stratejileri.Ankara:Eflatun Basim.

Akşam Gazetesi (2013). http://www.aksam.com.tr/yasam/nedir-bu-y-kusagi-modern-hippilermi-peter-pan-mi/haber-213751

Atasoy, B. (2013). Facebook ilk defa Fortune 500 Listesinde, http://www.socialmedia.co , Erişim Tarihi : 04.09.2013.

Baltaş, Z. (2011). Kurum içi Koçluk, İstanbul: Remzi Kitabevi.

Bloomberg Businessweek Türkiye (2013). 1982 -..... Kuşağı, 20 Ocak - 02 Şubat 2013.

Boyd,D.M. Ve Ellison,N.B. (2008). Social Network Sites: Definition, History and and Scholarship, Journal of Computer-Mediated Communication,13(1),210-230.

Bozkurt,A. (2010). Siyasiler Sosyal Medya Rüzgarının Farkında, Bilişim, Yı1:38, Sayı:27.

Broadbridge,A. , Maxwell, G.A Ogden, S.M., (2007). Experiences perceptions and expectations of retail employement for Generation Y , Career Development International, Volume 12, No:6.

Büyüköztürk,Ş. (2002). Sosyal Bilimler İçin Veri Analizi El Kitabı İstatistik Araştırma Deseni SPSS Uygulamaları ve Yorum, Ankara: Pegam Yayınları.

Çatalkaya, C. (2013). 'A'dan Z'ye Y Kuşağı', Kigem Gelişim Merkezi, http://www.kigem.com , 12.09.2013.

Dijital Ajanslar (2013). http://www.dijitalajanslar.com/y-kusagi , 04.09.2013

Edelman (2013). 8095 Araştırma Raporu.

Ergil,D. (2013). Y Kuşağı Yazısı, Bugün Gazetesi 04 Temmuz 2013.

Evans,D. (2008). Social Media Marketing: An Hour A Day. Kanada:Sybex.

Ipsos (2013). Ayna: Onlar Y Kuşağı Araştırması, UU Kalitatif Araştırmalar Birimi.

Kalaycı, Ş. (2005). SPSS Uygulamalı Çok Değişkenli İstatistik Teknikleri, Ankara: Asil Dağıtım.

Kara,T. (2012). Sosyal Medya Akademi,İstanbul: Beta Yayınları.

Kariyer Atölyesi (2013). http://www.kariyeratolyesi.com/kusak-nedir-kusaklar-kaca-ayrilirkusaklarin-ozellikleri-nelerdir , 05.09.2013

Kılıç, S,M. (2012). XYZ Kuşağı, Yeni Şafak ,15 Aralık 2012.

Kotler ,P. Ve Armstrong, G. (2004). Principles of Marketing, 10. Bask1, New Jersey: Prentice Hell.

Lower, J. (2008). Brace Yourself Here Comes Generation Y. Critical Care Nurse, 28 (5), 80,84 .

Marketing Türkiye (2013). Y Kuşağının Markalardan Beklentisi Azalıyor, 1 Mart 2013.

Para Ekonomi Dergisi (2013). İş Dünyasının Tatlı Belası Y Kuşağı, 16-22 Haziran 2013.

Queen, M,M. (2011). Ict Summit Eurasia- Bilişim Zirvesi Konuşması, Ekim 2011.

SilverPop (2013). En Popüler 20 Sosyal A $\breve{g}$, http://sosyalmedya.co/en-populer-20-sosyal-aginfografik/ Erişim Tarihi: 12.08.2013. 
Solis,B. (2011). Engage! The Complete Guide for Brands and Business to Build, Cultivate and Measure in the New Web, New Jersey: John Wiley and Sons.

Straus,W. , Howe, N. (1992). "Generations: The History of America's Future", 1584-2069, Quill.

TDK (2013). http://www.tdkterim.gov.tr , 09.06.2013.

Tufur, M. (2013). Türkiye'nin Y Kuşağı , Media Cat Dergisi, Mayıs 2013.

Usta,A. (2012). Yeni Kuşağı Anlamak, Bloomberg Businessweek Türkiye, 16-22 Aralık 2012.

Williams,C.K. Ve Page, A.R. (2011). Marketing to the Generations, Journal of Behavioral Studies in Business, 3, 3-11

Youth Research (2013). Yeni ekonominin Tüketiciler ile Markalar Arasındaki İlişki, Sabah Gazetesi,28.07.2013. 